\title{
ECONOMIC GEOLOGY OF RENARD 3, QUEBEC, CANADA: A DIAMONDIFEROUS, MULTI-PHASE PIPE INFILLED WITH HYPABYSSAL AND TUFFISITIC KIMBERLITE
}

\author{
Muntener $^{1 *}$ C and Scott Smith ${ }^{2}$ BH

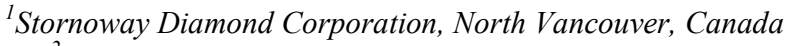 \\ ${ }^{2}$ Scott-Smith Petrology Inc., North Vancouver, Canada
}

\section{INTRODUCTION}

The Renard kimberlite cluster was discovered in 2001 in the Otish Mountains area of central Quebec, within the eastern portion of the Superior Craton. The Renard cluster consists of nine diamondiferous pipes emplaced at $640 \mathrm{Ma}$ into Archean gneiss-granitoid basement (Birkett et al., 2004). Three of the pipes host Indicated Resources and are undergoing a bankable feasibility study. The Indicated Resource of Renard 3 has an estimated macrodiamond content of 106 carats per hundred tonnes (cpht), the highest grade pipe in the cluster (Farrow, 2011). The external and internal geology were investigated to determine high confidence resource volumes and diamond contents, which were subsequently summarized in a three dimensional (3D) geological model. The investigation was based on the study of ninety drill cores, nine reverse circulation drill holes, underground bulk samples and exposures, together with representative petrographic samples (Fig. 1). The results demonstrate that Renard 3 is a multi-phase, steep-sided kimberlite body, infilled with hypabyssal and tuffisitic kimberlite and represents an eroded, deep diatreme to root zone pipe.

\section{MAIN ROCK TYPES}

The main rock types encountered include (a) in situ country rock which has not been affected by kimberlite emplacement and (b) rocks affected by, or resulting from, kimberlite emplacement. The latter rock types are broadly subdivided into (i) rocks dominated by country rock which include cracked country rock (CCR) and country rock breccia $(\mathrm{CRB})$ and (ii) rocks dominated by kimberlite (Figs. 1 and 2).

\section{Rocks Dominated by Country Rock}

The CCR is characterized by large blocks (observed up to $25 \mathrm{~m}$ ) of solid country rock showing minor displacement and separated by thin fracture zones which may, or may not,
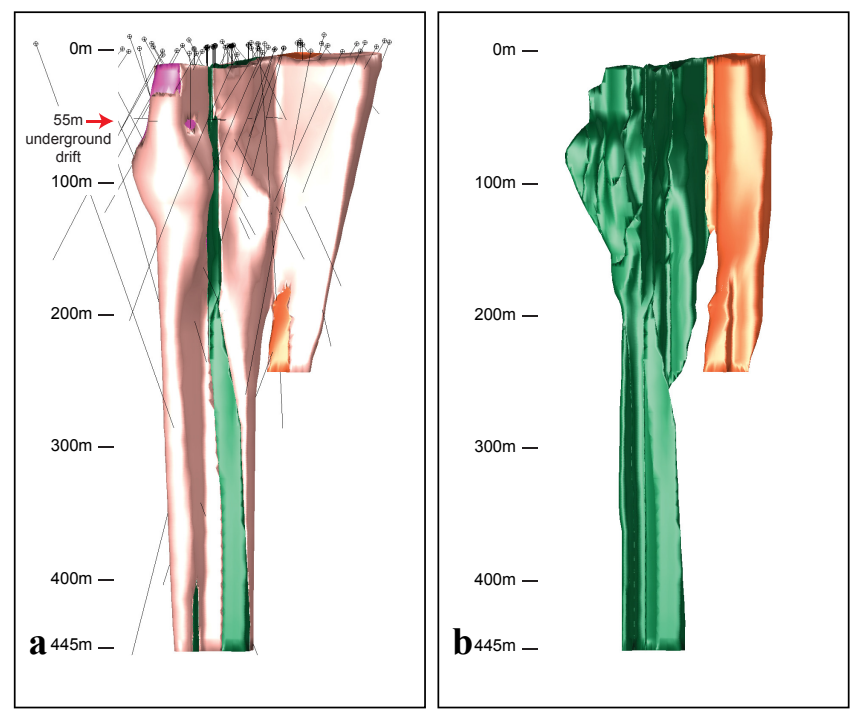

Figure 1: West facing view of the 3D geological model of Renard 3: (a) shows drill hole locations and traces, the depth of the underground bulk sampling drift, the cracked country rock (CCR; light pink) which surrounds the majority of the kimberlite (green and orange), the country rock breccia (CRB; dark pink) and the volcanic-pipe-like shape; (b) as (a) excluding the CCR and CRB, and combining the significant kimberlite units listed in Table 1 into two groups (green- units Kimb3h, Kimb3b, Kimb3dg and Kimb3f; and dark orange- Kimb3i), which correlate with the two feeder zones.

contain kimberlite. This unit surrounds the majority of the kimberlite body with steep and sharp contacts (Figs. 1a and 2 ). Compared to the CCR, the CRB is composed of smaller country rock fragments and blocks (up to $50 \mathrm{~cm}$ in size) which display a greater degree of rounding, displacement, mixing, and a higher proportion of kimberlite constituents within the interclast matrix. The CRB is located only in the southern, uppermost portion of the pipe (Figs. 1a and 2). The outer limit of these kimberlite-affected, country rockdominated units together defines a steep sided, volcanicpipe-like body, with an irregular plan view shape and a surface area of 0.8 hectares (Fig. 2). 


\section{$10^{\text {th }}$ International Kimberlite Conference, Bangalore - 2012}

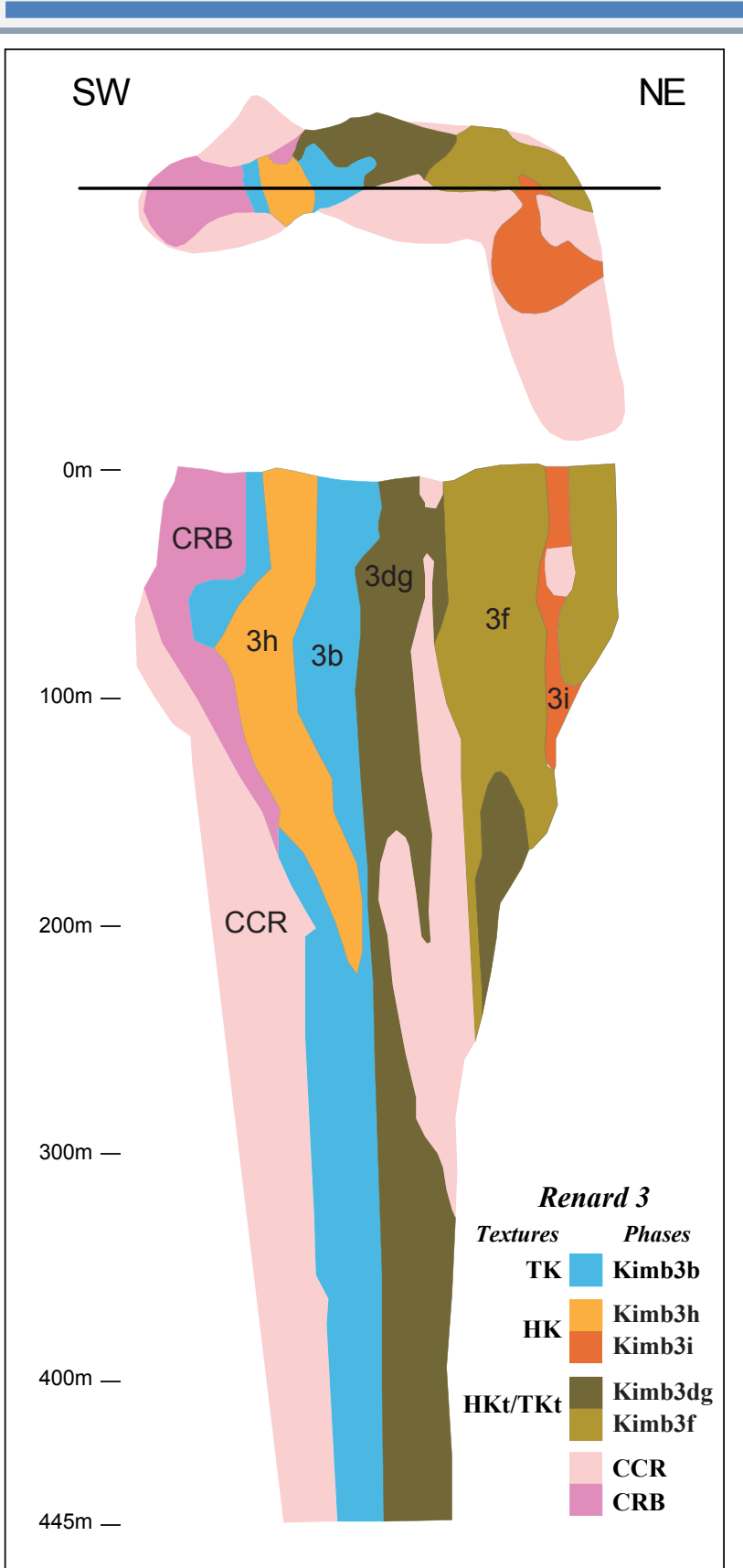

Figure 2: Plan view and cross section of the 3D geological model of Renard 3 detailing the location of the cracked country rock (CCR), country rock breccia $(\mathrm{CRB})$ and the kimberlite subdivided into different kimberlite phases and textural types (TK-tuffisitic kimberlite, HK-hypabyssal kimberlite, "t" transitional textures; Table 1).

\section{Rocks Dominated by Kimberlite}

The kimberlite-dominated rocks form a smaller, more irregular pipe-shaped body with two possible feeders (Fig. 1b) and a plan view area of 0.3 hectares (Fig. 2). Based on drilling to a depth of $445 \mathrm{~m}$, the pipe has a modeled kimberlite volume of $923,700 \mathrm{~m} 3$ (2.49 million tonnes). Seven separate kimberlite units were differentiated using a combination of megascopic, macroscopic and microscopic features as listed in Table 1. Textural varieties of
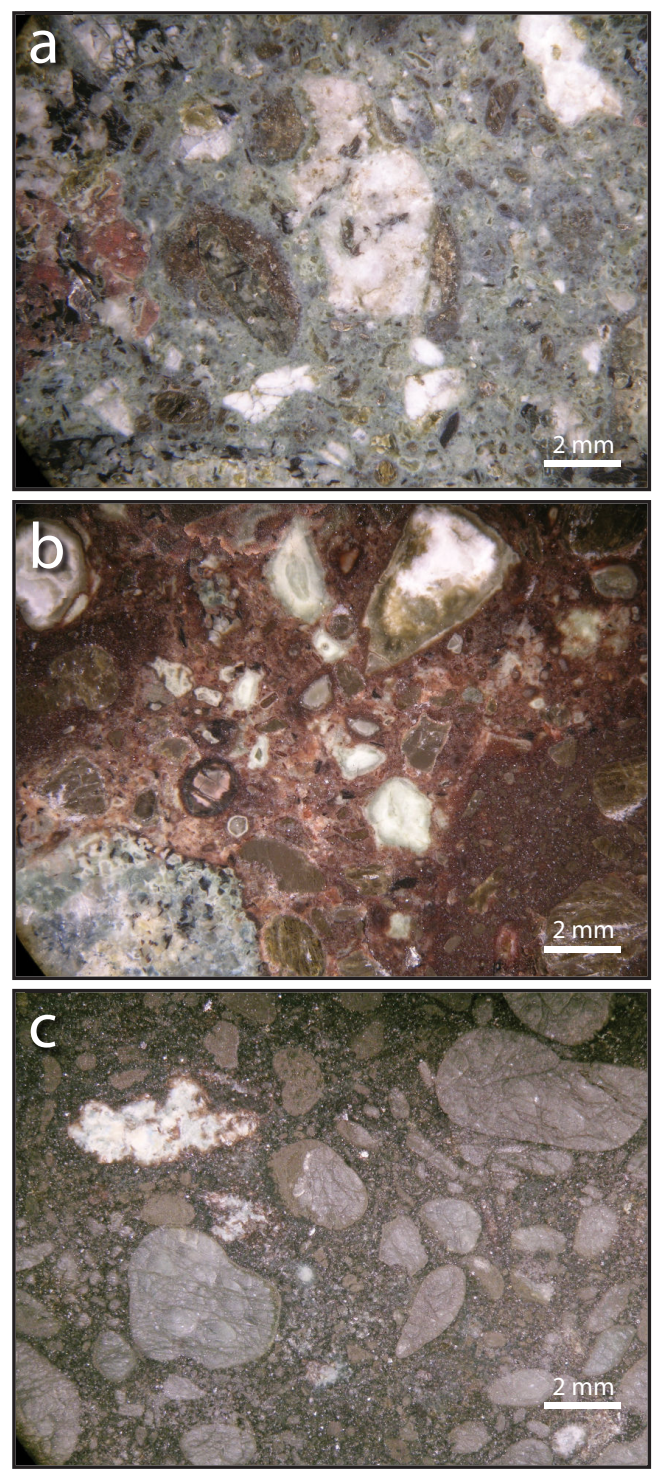

Figure 3: Main kimberlite textures present in Renard 3 (Fig. 2, Table 1): (a) tuffisitic kimberlite (TK) breccia (Kimb3b) with abundant, fresh, palecoloured basement xenoliths, and brown magmaclasts set in a very finegrained blue-grey matrix; (b) transitional textures between tuffisitic and hypabyssal kimberlite (TKt/HKt; Kimb3g) with partly reacted basement xenoliths, and brown magmaclasts set in a paler brown matrix; (c) hypabyssal kimberlite (HK; Kimb3i) with typical olivine macrocrystic texture and a low abundance of highly reacted, irregularly-shaped, lightcoloured basement xenoliths in a fine-grained crystalline groundmass. Note the alteration halo surrounding the white, highly reacted xenolith in (c) contains serpentinized olivine macrocrysts compared to fresh olivine macrocrysts in the bottom portion of the photograph. Also note the differences between (a) and (c) and that the features in (b) are intermediate between these two end members.

kimberlite present include: (i) volcaniclastic kimberlite that is classified as tuffisitic kimberlite breccia (TK; Fig. 3a), (ii) coherent kimberlite that is classified as hypabyssal kimberlite (HK; Fig. 3c) and (iii) transitional kimberlite that is intermediate between tuffisitic and hypabyssal (TKt, HKt, respectively; Fig. 3b). Textural terminology is after Hetman et al. (2004). 


\section{$10^{\text {th }}$ International Kimberlite Conference, Bangalore - 2012}

Table 1: Summary of the Megascopic, Macroscopic and Microscopic Features of the Renard 3 Kimberlite Units.

\begin{tabular}{|c|c|c|c|c|c|c|c|}
\hline Renard 3 & Kimb3b & Kimb3f & Kimb3 $\mathrm{g}^{*}$ & Kimb3d* & Kimb3h & Kimb3i & Kimb3c \\
\hline Kimberlite Texture & $\mathrm{TK}$ & $\mathrm{TKt} / \mathrm{HKt}$ & $\mathrm{HKt} / \mathrm{TKt}$ & $\mathrm{HK} / \mathrm{HKt}$ & $\mathrm{HK}$ & $\mathrm{HK}$ & $\mathrm{HK}$ \\
\hline $\begin{array}{l}\text { Macroscopic Matrix } \\
\text { Colour }\end{array}$ & Blue to Blue-Green & $\begin{array}{l}\text { Brown to Mottled } \\
\text { Blue-Green }\end{array}$ & Brown to Dark Brown & Black to Dark Brown & Black & Black & $\begin{array}{l}\text { Dark Green, Grey or } \\
\text { Black }\end{array}$ \\
\hline $\begin{array}{l}\text { Xenolith } \\
\text { Abundance }\end{array}$ & $55-75 \%$ & $35-50 \%$ & $30-50 \%$ & $20-45 \%$ & $15-25 \%$ & $10-20 \%$ & $0-10 \%$ \\
\hline $\begin{array}{l}\text { Dominant Xenolith } \\
\text { Size }\end{array}$ & $<20 \mathrm{~cm}$ & $<10 \mathrm{~cm}$ & $<10 \mathrm{~cm}$ & $<6 \mathrm{~cm}$ & $<3 \mathrm{~cm}$ & $<3 \mathrm{~cm}$ & $<5 \mathrm{~cm}$ \\
\hline $\begin{array}{l}\text { Maximum Xenolith } \\
\text { Size }\end{array}$ & $200 \mathrm{~cm}$ & $70 \mathrm{~cm}$ & $60 \mathrm{~cm}$ & $10 \mathrm{~cm}$ & $25 \mathrm{~cm}$ & $6 \mathrm{~cm}$ & $5 \mathrm{~cm}$ \\
\hline Xenolith Shape & Angular & Subangular > Subround & Subround > Subangular & Subround > Subangular & Subround > Subangular & Subround $>$ Round & Subround > Subangular \\
\hline $\begin{array}{l}\text { Degree of Xenolith } \\
\text { Reaction }\end{array}$ & None to Low & Moderate & Moderate & High to Moderate & High & High & High \\
\hline $\begin{array}{l}\text { Xenolith Reaction } \\
\text { Color }\end{array}$ & $\begin{array}{l}\text { None to pink or } \\
\text { light green }\end{array}$ & $\begin{array}{c}\text { Cream yellow rims to } \\
\text { medium green }\end{array}$ & $\begin{array}{c}\text { Cream yellow rims to } \\
\text { medium green }\end{array}$ & $\begin{array}{l}\text { Dark green to black } \\
\text { halos, or partial } \\
\text { bleached centers }\end{array}$ & $\begin{array}{l}\text { Bleached to dark } \\
\text { green }\end{array}$ & $\begin{array}{l}\text { Dark green-black } \\
\text { to bleached }\end{array}$ & $\begin{array}{l}\text { Bleached to dark } \\
\text { green }\end{array}$ \\
\hline $\begin{array}{l}\text { Autolith } \\
\text { Abundance }\end{array}$ & Occasional & Common & $\begin{array}{l}\text { Occasional to } \\
\text { common }\end{array}$ & Absent & Absent & Absent & Absent \\
\hline $\begin{array}{l}\text { Mantle Xenolith } \\
\text { Abundance }\end{array}$ & Rare & Occasional & Rare & Rare & Absent & Common & Rare \\
\hline $\begin{array}{l}\text { Magmaclast } \\
\text { Abundance }\end{array}$ & $\begin{array}{l}\text { Abundant to } \\
\text { Common }\end{array}$ & Common & $\begin{array}{l}\text { Occasional to } \\
\text { Common }\end{array}$ & Absent & Absent & Absent & Absent \\
\hline $\begin{array}{l}\text { Total Olivine } \\
\text { Abundance }\end{array}$ & $10-20 \%$ & $15-30 \%$ & $20-40 \%$ & $40-50 \%$ & $35-50 \%$ & $40-60 \%$ & $\geq 50 \%$ \\
\hline $\begin{array}{l}\text { Olivine Macrocryst } \\
\text { Abundance }\end{array}$ & $7-13 \%$ & $13-23 \%$ & $10-20 \%$ & $20-25 \%$ & $20-35 \%$ & $25-30 \%$ & $25-30 \%$ \\
\hline $\begin{array}{l}\text { Olivine Macrocryst } \\
\text { Size }{ }^{* *}\end{array}$ & F-M-(C) & M-C-((VC)) & M-C-((VC)) & M-C-(VC) & M-C-((VC)) & M-C-(VC) & M-C-(VC) \\
\hline $\begin{array}{l}\text { Degree of Olivine } \\
\text { Replace ment }\end{array}$ & Complete & Complete & Complete & None to Complete & None to Complete & None to Complete & None to Complete \\
\hline $\begin{array}{l}\text { Type of Olivine } \\
\text { Replace ment }{ }^{* * *}\end{array}$ & $\begin{array}{c}\text { Serpentine, } \\
\text { clinopyroxene, clay }\end{array}$ & $\begin{array}{c}\text { Serpentine, } \\
\text { clinopyroxene, talc, } \\
\text { clay }\end{array}$ & Serpentine & Serpentine, carbonate & Serpentine, carbonate & Serpentine & Serpentine, carbonate \\
\hline \multirow{7}{*}{$\begin{array}{l}\text { Groundmass } \\
\text { Minerals } * * * *\end{array}$} & Clinopyroxene & Clinopyroxene & Phlogopite & Phlogopite & Carbonate & Carbonate & Phlogopite \\
\hline & Phlogopite & Phlogopite & Clinopyroxene & Carbonate & Serpentine & Serpentine & Carbonate \\
\hline & Serpentine & Perovskite & Perovskite & Perovskite & Phlogopite & Phlogopite & Serpentine \\
\hline & Spinel & Spinel & Spinel & Spinel & Spinel & Perovskite & Spinel \\
\hline & Perovskite & Serpentine & Carbonate & Clinopyroxene & Perovskite & Spinel & Perovskite \\
\hline & & Richterite & Serpentine & Monticellite & Monticellite & & \\
\hline & & & & Serpentine & Apatite & & \\
\hline
\end{tabular}

*Note Kimb3g and Kimb3d have been modeled together in the 3D model; **F: 0.5-2mm; M: 2-5mm; C: 5-10mm; VC: >10mm; ***First descriptor is the most dominant of the list; **** Serpentine, Carbonate and Clinopyroxene abundances are variable within samples.

Rocks termed HK can be subdivided into pipe-fill HK units (Kimb3h and Kimb3i; Fig. 3c) and small intrusions and sheets (Kimb3c) which cross cut either the country rock or other pipe-fill units. The other textural end member, TK, is the dominant rock type in unit Kimb3b, (Figs. 3a and 4), allowing easy differentiation from all other kimberlite units. Units with intermediate and transitional textures between HK and TK (TKt, HKt) are more difficult to subdivide. Unit Kimb3f is texturally closer to a TK (TKt/HKt), and contains abundant HK autoliths, and very fine laths of latestage, primary groundmass richterite within both the magmaclasts and the inter-magmaclast matrix. Two other units lacking richterite and abundant autoliths are distinguished using textures (HKt/TKt - Kimb3g; HK/HKt Kimb3d). Although the latter two units are texturally distinct, several other characteristics suggested they were similar in nature, leading to them being modeled as a single unit (Kimb3dg). Kimb3c represents a group of small discrete intrusions which occur throughout Renard 3 (including within CCR and CRB), typically along contacts between different kimberlite units or the country rockdominated units. These intrusions are too difficult to correlate and thus are not included in the 3D model.

\section{INTERNAL GEOLOGICAL MODEL}

The modeled 3D spatial distribution of the five main kimberlite units is shown in Figure 2. Together they form the irregular pipe-shaped body shown in Figure 1b. The observed textures within each of these units are internally consistent over the modeled depth of $445 \mathrm{~m}$. When observed, internal contacts are sharp and steeply dipping (Fig. 4). The nature of the internal contacts and the distinct units indicates that they represent vertically extensive, pipeforming phases of kimberlite, emplaced from separate batches of magma.

The distribution of kimberlite phases (Fig. 2) indicates that 


\section{$10^{\text {th }}$ International Kimberlite Conference, Bangalore - 2012}

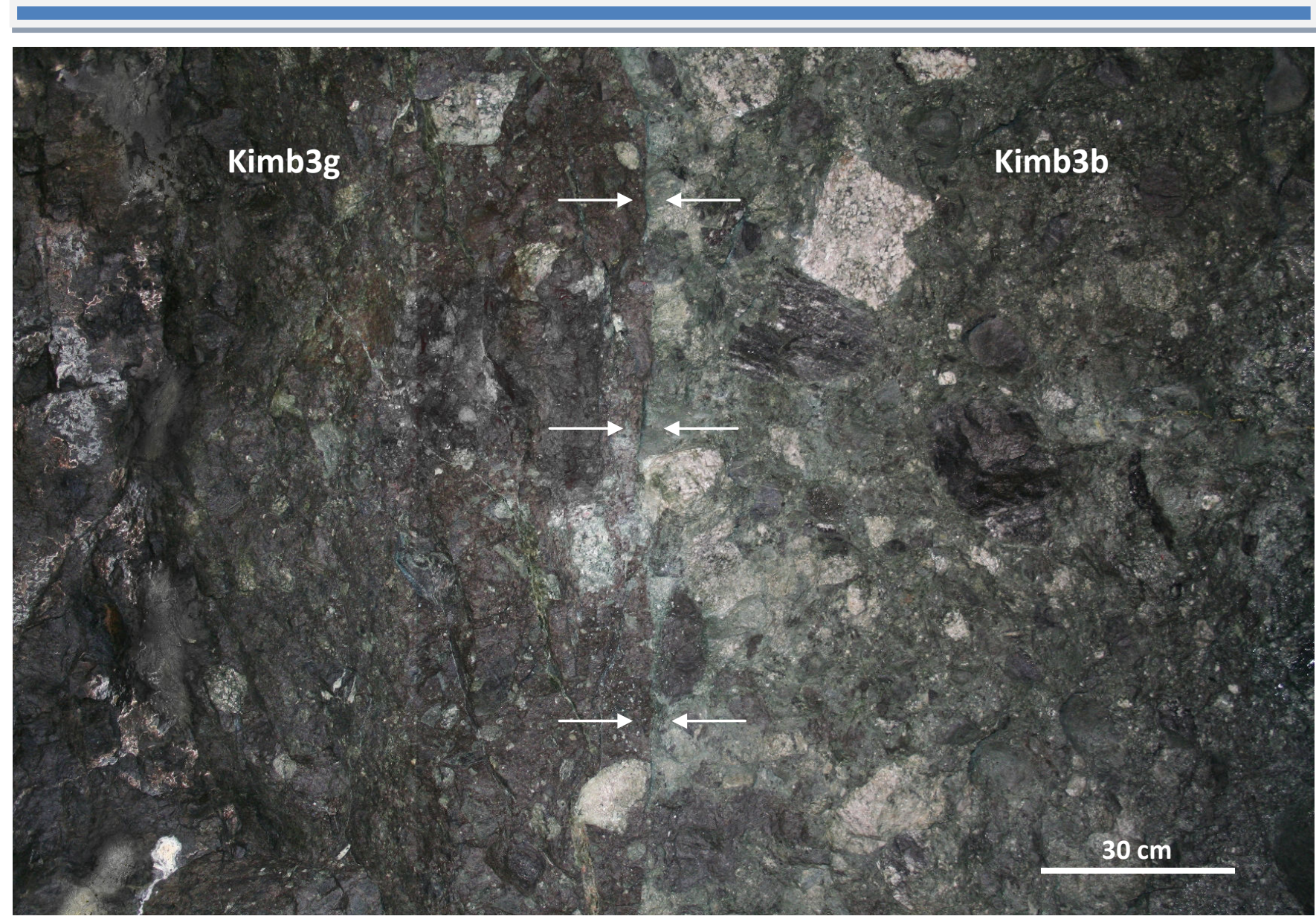

Figure 4: Sharp, vertical contact (shown by arrows) between two kimberlite units within the Renard 3 pipe (Kimb3g-left; Kimb3b-right: Fig. 2) as seen in the underground drift, location in Figure 1a. Note the difference in rock colour, xenolith abundance, size, shape, and reaction as listed in Table 1. The macroscopic textures of these units are shown in Figures $3 a$ and $b$.

two separate feeder systems are preserved within Renard 3. The northeast intrusion is defined by a single phase of HK (Kimb3i), forming an irregularly shaped intrusion enveloped mostly by CCR and becoming more sheet-like at depth. The southwest intrusion is more complex and hosts the remaining kimberlite phases, revealing a pipe-like shape to the modeled depth of $445 \mathrm{~m}$. Kimb3f has not been encountered at sufficient depth from surface to allow direct correlation with either of the feeders but based on its distribution, is interpreted to be associated with the southwest feeder and older than the two adjacent kimberlite phases (Kimb3i and Kimb3dg).

\section{CONCLUSION}

Renard 3 is interpreted to be a steep-sided pipe, formed by the emplacement of multiple, texturally distinct, crosscutting phases of kimberlite with near-vertical and predominantly sharp internal contacts. Bulk sampling indicates contrasting macrodiamond grades within the pipe which correlate with, and strongly support, the modeled internal kimberlite phases (Table 2).
Table 2: Diamond Sampling Results for Kimberlite Phases of Renard 3.

\begin{tabular}{|l|c|c|}
\hline $\begin{array}{c}\text { Kimberlite } \\
\text { Phase }\end{array}$ & $\begin{array}{c}\text { Proportional } \\
\text { Volume in the } \\
\text { Kimberlite Pipe }\end{array}$ & Grade* (cpht) \\
\hline Kimb3dg & $46 \%$ & 146 \\
\hline Kimb3h & $11 \%$ & 192 \\
\hline Kimb3f & $10 \%$ & 88 \\
\hline Kimb3i & $15 \%$ & 33 \\
\hline Kimb3b** & $16 \%$ & 101 \\
\hline
\end{tabular}

*Diamond grades are based on the recovered sample grades from individual bulk sample rounds extracted during 2006/07 from the underground drift shown in Figure 1 for units Kimb3dg, Kimb3h, Kimb3f, Kimb3b and Kimb3c and the 2007 reverse circulation drilling bulk sampling program for unit Kimb3i. Kimb3c is approximately $15 \%$ of the modeled kimberlite pipe with a diamond grade of $230 \mathrm{cpht}$. **Diamond grade for units Kimb3b and Kimb3c are estimated through a back calculation using recovered grade contributions and volume proportions from underground bulk sample rounds (Farrow, 2011). Note, the diamond grades presented here for each geological unit may not be representative of the overall diamond content of the body due to a number of factors, including location/size of the samples and processing parameters. 
The combination of observed kimberlite textures, rock types, associated country rock features, emplacement age and regional geological setting indicate that Renard 3 is an eroded, deep-diatreme to root zone kimberlite pipe, similar to Renard 2 (Fitzgerald, 2009) and comparable to those in southern Africa and at Gahcho Kué, NT, Canada (Field and Scott Smith, 1999; Hetman et al., 2004). The correlations between Renard 3 and these pipes significantly increases the degree of confidence in the geological model and in turn the Indicated Resource estimates (Farrow, 2011), highlighting the importance of kimberlite geology and the methodology required in the economic assessment of a kimberlite.

\section{References}

Birkett, T.C., McCandless, T.E., Hood, C.T., 2004. Petrology of the Renard igneous bodies: host rocks for diamond in the northern Otish Mountains, Quebec, Canada. Proceedings of the 8th International Kimberlite Conference, Volume 1, Lithos, 76, pp. 475-490.

Farrow, D. 2011. Technical report of 2010 Mineral Resource update for the Renard diamond project. NI-43101 Report, prepared for Stornoway Diamond Corporation, 125pp.

Field, M. and Scott Smith, B.H., 1999. Contrasting geology and nearsurface emplacement of kimberlite pipes in southern Africa and Canada. In: Gurney, J.J., Gurney, J.L., Pascoe, M.D., Richardson, S.H. (Eds.), Proceedings of the 7th International Kimberlite Conference, 1. Red Roof Design, Cape Town, pp. 214-237.

Fitzgerald, C.E., Hetman, C.M., Lépine, I., Skelton, D.S., and McCandless, T.M., 2009. The internal geology and emplacement history of the Renard 2 kimberlite, Superior Province, Quebec, Canada. Proceedings of the 9th International Kimberlite Conference, Lithos, 112, Supplement 1., pp. 513-528.

Hetman, C.M., Scott Smith, B.H., Paul, J.L., Winter, F.W., 2004. Geology of the Gahcho Kue kimberlite pipes, NWT, Canada: root to diatreme transition zones, Proceedings of the 8th International Kimberlite Conference, Lithos 76, pp. 183-200. 